\title{
Physicochemical and Microbiological Characteristics of Thermal Healing Spring Waters in the District of Varna
}

\author{
Nedyalka Valcheva $^{1^{*}} \quad$ Ignat Ignatov $^{2}$ \\ 1. PhD, Faculty of Agriculture, Department „Biochemistry, Microbiology, Physics“, Trakia University, Stara \\ Zagora 6000, Bulgaria \\ 2. DSc, Professor, Scientific Research Center of Medical Biophysics (SRCMB), N. Kopernik Street, 32, Sofia
}

1111, Bulgari

\begin{abstract}
Defined are the physicochemical properties of healing thermal and non-thermal spring waters in the area of Varna District. It is shown that according to 18 controlled parameters included in the research, the thermal healing spring water drilling №P-83xKK "Saints Constantine and Helena", thermal healing spring water P-1x "Aquarium", thermal healing spring water P-106 x "Dom Mladost", thermal healing spring water P-161x Varna at "Primorski" swimming pool, fulfill the required conditions for drinking water.The spring waters from the given four water sources are characterized by microbiological indicators, as the pathogenic micro-organisms are defined by the membrane method. It is established that thermal healing spring water drilling №P-83xKK "Saints Constantine and Helena", thermal healing spring water P-1x "Aquarium", thermal healing spring water P-106 x "Dom Mladost", thermal healing spring water P-161x Varna at "Primorski" swimming pool, fulfill the standard requirements. "The healing water" of village Goren Chiflik, District of Varna does not conform with the physicochemical indicators given for nitrates, and microbiological indicators with regards to coliform bacteria and enterococci.
\end{abstract}

Keywords: spring water, drinking water, physicochemical properties, microbiological indicators

DOI: $10.7176 / \mathrm{JMPB} / 59-02$

Publication date:September $30^{\text {th }} 2019$

\section{Introduction}

Bulgaria is one of the richest in mineral springs countries in Europe. It takes second place after Iceland. Their total number is around 225. Based on their location are observed certain specifics. The ones to the north of Balkan are with lower temperatures, and are reached usually via drilling. Their total number is almost half the amount of the ones to the south of Old Mountain. There are around 148 known springs from Southern Bulgaria. Predominant in them are the ones with natural origin and higher temperature of the water. The causes for that lie in the combination between hydrological conditions of the continuing tectonic processes in the Earth's crust [Ignatov., 2010]. By their nature the springs can be separated in cold, warm and hot springs. The first group includes the ones with temperature up to $37^{\circ} \mathrm{C}$, the second one ranges between $37^{\circ} \mathrm{C}$ and $60^{\circ} \mathrm{C}$, and the third one with over $60^{\circ} \mathrm{C}$. The hottest mineral spring in Bulgaria is the one at Sapareva Banya with temperature of $101,4^{\circ} \mathrm{C}$. The springing waters have different mineralogical characteristics. Their content is defined by the ones of the rocks, where the water has been flowing through, and the solubility of the minerals within them [Ignatov, Mosin, 2012].

\section{Mineral springs in Varna district}

Health resort "Saints Constantine and Helena" is the first Bulgarian resort at Black Sea. One of the most important conditions for the resort development is the availability of 7 mineral springs with no analogue in Europe. They are calcium-magnesium, with low mineralization and come from depth of 1800 to 2050 meters under the ground with total flow rate of $175 \mathrm{l} / \mathrm{sec}$. The temperature of the water varies between 40 and 60 degrees centigrade, it can heal successfully cardiovascular diseases, the endocrine system, illnesses of the musculoskeletal system and the functional nervous system, myocardial infarction.

\section{Thermal healing spring, city of Varna 2 ( P-1x "Aquarium")}

- Healing prophylactic properties of the mineral water-the drinking thermal cure has positive influence over gastro-intestinal tract, biliary liver system and kidney excretory system. The presence of calcium proves to be suitable for application of mineral water for treatment of dental caries, as well as osteoporosis of any kind.

\section{Thermal healing spring Varna (P-106 x "Dom Mladost")}

The water comes via drilling with depth $1980 \mathrm{~m}$, and it is thermal with temperature of $47^{\circ} \mathrm{C}$. It cures conditions of cardiovascular system, of peripheral nervous system, digestive system, gynaecological diseases and posttraumatic stress disorders. 


\section{Non-thermal healing spring “Healing water", village of Goren Chiflik}

Healing water that can be ignited and can burn, it springs up in the locality Botevo near Dolni Chiflik. That is due to the methane contained within it. The water comes up years ago after drilling for natural gas. The phenomenal liquid springs up like a geyser from 600 meters depth. Research shows that the water contains around $30 \%$ iodine and helps for gastro-intestinal conditions, arthritis, skin and eye diseases.

\section{Materials and methods}

In the work are used thermal healing waters from the district of Varna - thermal healing spring Varna 1 (Healing resort "Saints Constantine and Helena") with water temperature of $48^{\circ} \mathrm{C}$, thermal healing spring city of Varna 2 (P-1x "Aquarium) with water temperature of $47^{\circ} \mathrm{C}$, thermal healing spring Varna 3 (P-106 x "Dom Mladost") with water temperature of $40^{\circ} \mathrm{C}$, thermal healing spring Varna 4 (P-161x Varna at swimming pool "Primorski") with water temperature of $50^{\circ} \mathrm{C}$, non-thermal healing spring "Healing water", village of Goren Chiflik.

\subsection{Nutrient media}

Nutrient agar (MPA) with contents (in $\%$ ) - meat water, peptone $-1 \%$, agar - agar $-2 \%$.

Endo's Medium (for defining of Escherichia coli and coliform bacteria) with contents $\left(\mathrm{g} / \mathrm{dm}^{3}\right)-$ peptone $-5,0$; triptone $-5,0$; lactose $-10,0 ; \mathrm{Na}_{2} \mathrm{SO}_{3}-1,4 ; \mathrm{K}_{2} \mathrm{HPO}_{4}-3,0$; fuchsine $-0,14$; agar - agar - 12,0 $\mathrm{pH} 7,5-7,7$. Nutrient gelatine (MPD) (for defining of Pseudomonas aeruginosa) with contents (in\%) - Peptic digest of animal tissue; $25 \%$ gelatin ; $\mathrm{pH}=7,0-7,2$.

Medium for defining of enterococci (esculin - bile agar).

Medium for defining of sulphite reducing bacteria (Iron Sulfite Modified Agar).

Wilson-Bleer medium (for defining of sulphite reducing spore anaerobes (Clostridium perfringens) with contents $\left(\mathrm{g} / \mathrm{dm}^{3}\right)-3 \%$ Nutrient agar; $100 \mathrm{~cm}^{3} 20 \%$ solution $\mathrm{Na}_{2} \mathrm{SO}_{3} ; 50 \mathrm{~cm}^{3} 20 \%$ glucose solution; $10 \mathrm{~cm}^{3} 8 \%$ solution of $\mathrm{Fe}_{2} \mathrm{SO}_{4}$.

\subsection{Methods for analysis}

\subsubsection{Methods for physicochemical analysis}

1. Method for determination of colour according to Rublyovska Scale - method by Bulgarian State Standard (BDS) $8451: 1977$;

2. Method for determination of smell at $20^{\circ} \mathrm{C}$ - method BDS $8451: 1977$ technical device - glass mercury thermometer, conditions No 21;

3. Method for determination of turbidity - EN ISO 7027, technical device turbidimeter type TURB 355 IR ID No 200807088;

4. Method for determination of $\mathrm{pH}-\mathrm{BDS} 3424$ : 1981, technical device $\mathrm{pH}$ meter type UB10 ID No UB10128148;

5. Method for determination of oxidisability - BDS $3413: 1981$;

6. Method for determination of chlorides - BDS 3414 : 1980;

7. Method for determination of nitrates - Validated Laboratory Method (VLM) - $\mathrm{NO}_{3}-$ No 2, technical device photometer "NOVA 60 A" ID No 08450505;

8. Method for determination of nitrites - VLM NO $3-$ No 3, technical device photometer "NOVA 60 A" ID No 08450505;

9. Method for determination of ammonium ions - VLM - $\mathrm{NH}_{4}-$ No 1, technical device photometer "NOVA 60 A" ID No 08450505;

10. Method for determination of general hardness - BDS ISO 6058;

11. Method for determination of sulphates - VLM - $\mathrm{SO}_{4}-\mathrm{No} 4$, technical device photometer "NOVA 60 A" ID No 08450505 ;

12. Method for determination of calcium - BDS ISO 6058;

13. Method for determination of magnesium - BDS $7211: 1982$;

14. Method for determination of phosphates - VLM - $\mathrm{PO}_{4}-\mathrm{No} 5$, technical device photometer "NOVA 60 A" ID No 08450505;

15. Method for determination of manganese - VLM - Mn - No 7, technical device photometer "NOVA 60 A" ID № 08450505;

16. Method for determination of iron - VLM - Fe - No 6, technical device photometer "NOVA 60 A" ID No 08450505 ;

17. Method for determination of fluorides - VLM - F - No 8, technical device photometer "NOVA 60 A" ID No 08450505 ;

18. Method for determination of electrical conductivity - BDS EN 27888, technical device - conductivity meter inoLab cond 720 ID No 11081137. 


\subsubsection{Methods for determination of microbiological indicators}

1. Methods for evaluation of microbiological indicators according to Ordinance No 9 / 2001, Official State Gazette, issue 30, and decree No 178 / 23.07.2004 about the quality of water, intended for drinking purposes.

2. Method for determination of Escherichia coli and coliform bacteria - BDS EN ISO 9308 - 1: 2004;

Method for determination of enterococci - BDS EN ISO $7899-2$

3. Method for determination of sulphite reducing spore anaerobes - BDS EN $26461-2: 2004$;

4. Method for determination of total number of aerobic and facultative anaerobic bacteria - BDS EN ISO 6222 : 2002 ;

5. Method for determination of Pseudomonas aeruginosa - BDS EN ISO $16266: 2008$.

6. Determination of coli - titre by fermentation method - Ginchev's method

7. Determination of coli - bacteria over Endo's medium - membrane method.

Determination of sulphite reducing anaerobic bacteria (Clostridium perfringens) - membrane method.

\section{Results and discussion}

It is done a comparative physicochemical analysis of mineral spring waters at the territory of Varna District by the main indicators (colour according to Rublyovska Scale, smell at $20^{\circ} \mathrm{C}$, turbidity, $\mathrm{pH}$, oxidisability, chlorides, nitrates, nitrites, ammonium ions, general hardness, sulphates, calcium, magnesium, phosphates, manganese, iron, fluorides, electrical conductivity). The results from these examinations are given in Table 1.

Table 1. Comparison of the examined spring waters in Varna District by physicochemical properties

\begin{tabular}{|c|c|c|c|c|c|c|}
\hline $\begin{array}{l}\text { Controlled } \\
\text { parameter }\end{array}$ & $\begin{array}{c}\text { Measuring } \\
\text { unit }\end{array}$ & $\begin{array}{l}\text { Maximu } \\
\text { m Limit } \\
\text { Value }\end{array}$ & $\begin{array}{c}\text { Result } \\
\text { Varna 1 } \\
\text { (drilling №P- } \\
\text { 83xKK } \\
\text { „Saints } \\
\text { Constantine } \\
\text { and Helena") }\end{array}$ & $\begin{array}{c}\text { Result } \\
\text { Varna 2 } \\
\text { (P-1x } \\
\text { "Aquarium") }\end{array}$ & $\begin{array}{c}\text { Result } \\
\text { Varna 3 } \\
\text { (P-106 x } \\
\text { "Dom } \\
\text { Mladost") }\end{array}$ & $\begin{array}{c}\text { Result } \\
\text { Varna 4 } \\
\text { (P-161x } \\
\text { Varna } \\
\text { "Primorski" } \\
\text { swimming } \\
\text { pool) }\end{array}$ \\
\hline $\begin{array}{l}\text { 1. Color } \\
\text { according to }\end{array}$ & $\begin{array}{c}\text { Chromaticity } \\
\text { Values }\end{array}$ & $\begin{array}{l}\text { Acceptabl } \\
\text { to consume }\end{array}$ & $\begin{array}{c}\text { Acceptable to } \\
\text { consumers }\end{array}$ & $\begin{array}{c}\text { Acceptable to } \\
\text { consumers }\end{array}$ & $\begin{array}{c}\text { Acceptable } t \\
\text { consumers }\end{array}$ & $\begin{array}{c}\text { Acceptable to } \\
\text { consumers }\end{array}$ \\
\hline $\begin{array}{l}\text { Rublyovska } \\
\text { Scale }\end{array}$ & & & & & & \\
\hline $\begin{array}{l}\text { 2. Smell at } \\
20^{\circ} \mathrm{C}\end{array}$ & Rating & $\begin{array}{l}\text { Acceptabli } \\
\text { to consume }\end{array}$ & $\begin{array}{l}\text { Acceptable to } \\
\text { consumers }\end{array}$ & $\begin{array}{l}\text { Acceptable to } \\
\text { consumers }\end{array}$ & $\begin{array}{c}\text { Acceptable } t \\
\text { consumers }\end{array}$ & $\begin{array}{c}\text { Acceptable to } \\
\text { consumers }\end{array}$ \\
\hline 3. Turbidity & NTU & $\begin{array}{l}\text { Acceptabli } \\
\text { to consume }\end{array}$ & $\begin{array}{c}\text { Acceptable to } \\
\text { consumers }\end{array}$ & $\begin{array}{c}\text { Acceptable to } \\
\text { consumers }\end{array}$ & $\begin{array}{c}\text { Acceptable } t \\
\text { consumers }\end{array}$ & $\begin{array}{c}\text { Acceptable to } \\
\text { consumers }\end{array}$ \\
\hline 4.pH & рН единици & $\begin{array}{c}\geq 6,5 \text { и } \\
9,5\end{array}$ & 7,79 & 7,6 & 9,48 & 9,46 \\
\hline 5. Oxidisability & $\mathrm{mgO}_{2} / \mathrm{dm}^{3}$ & 5,0 & 2,1 & 1,6 & 1,9 & 1,2 \\
\hline 6. Chlorides & $\mathrm{mg} / \mathrm{dm}^{3}$ & 250 & 64,41 & 104 & 130 & 96 \\
\hline 7. Nitrates & $\mathrm{mg} / \mathrm{dm}^{3}$ & 50 & 0,9 & 2,9 & 2,1 & 4,9 \\
\hline 8. Nitrites & $\mathrm{mg} / \mathrm{dm}^{3}$ & $\mathbf{0 , 5 0}$ & 0,04 & 0,04 & 0,00 & 0,004 \\
\hline $\begin{array}{l}\text { 9. Ammonium } \\
\text { ions }\end{array}$ & $\mathrm{mg} / \mathrm{dm}^{3}$ & 0,50 & 0,04 & 0,29 & 0,21 & $\mathbf{0 , 8 5}$ \\
\hline 10. Hardness & mgekv/ $\mathbf{d m}^{3}$ & 12 & 4 & 3,9 & 11,5 & 11,5 \\
\hline 11. Sulphates & $\mathrm{mg} / \mathbf{d m}^{3}$ & 250 & 36,21 & 77 & 62 & 76 \\
\hline 12. Calcium & $\mathrm{mg} / \mathrm{dm}^{3}$ & 150 & 53,11 & 43 & 118 & 120 \\
\hline 13. Magnesium & $\mathrm{mg} / \mathrm{dm}^{3}$ & 80 & 32,83 & 27 & 68 & 67 \\
\hline 14. Phosphates & $\mathrm{mg} / \mathrm{dm}^{3}$ & 0,5 & 0,02 & 0,03 & 0,02 & $\mathbf{0 , 0 2}$ \\
\hline 15. Manganese & $\mathrm{mg} / \mathrm{dm}^{3}$ & 50 & 0,01 & 0,001 & 0,009 & 0,05 \\
\hline 16. Iron & $\mu g / d^{3}$ & 200 & $\mathbf{0 , 0 5}$ & 59 & 481 & $<5$ \\
\hline 17. Fluorides & $\mathrm{mg} / \mathrm{dm}^{3}$ & 1,5 & 0,43 & 0,71 & 0,55 & 0,62 \\
\hline $\begin{array}{l}\text { 18. Electrical } \\
\text { conductivity }\end{array}$ & $\mu \mathrm{S} / \mathrm{dm}^{3}$ & 2000 & 694 & 768 & 350 & \\
\hline
\end{tabular}

The trial data reveal that thermal healing spring water drilling №P-83xKK "Saints Constantine and Helena", thermal healing spring water P-1x "Aquarium", thermal healing spring water P-106 x "Dom Mladost", thermal healing spring water P-161x at "Primorski" swimming pool are in compliance with the controlled parameters set out in Ordinance № 9 / 2001, Official State Gazette, issue 30, and decree № 178 / 23.07.2004 about the quality of water, intended for drinking purposes. The "Healing water", village of Goren Chiflik, District of Varna is not in compliance with regards to nitrates - higher than 130 milligrams per liter (RZI (Regional Health Inspection) - 
Varna).

For the same spring waters are determined their microbiological indicators by the membrane method. In Table 2 are shown the experimental studies from the determination of total number of mesophilic aerobic and facultative anaerobic bacteria.

\section{Table 2}

Determination of total number of mesophilic aerobic and facultative anaerobic bacteria

\begin{tabular}{|c|c|}
\hline Examined water source & $\begin{array}{c}\text { Indicator, } \\
\mathrm{cfu} / \mathrm{cm}^{3}\end{array}$ \\
\hline $\begin{array}{l}\text { 1. Thermal healing spring Varna } 1 \\
\text { (drilling №P-83x Health Resort ,Saints Constantine and Helena") with water temperature } \\
\text { of } 48^{\circ} \mathrm{C}\end{array}$ & $4 \pm 1$ \\
\hline $\begin{array}{l}\text { 2. Thermal Healing Spring Varna } 2 \mathrm{P}-1 \mathrm{x} \text { "Aquarium" ) with water temperature of } 47^{\circ} \mathrm{C} \\
\text { 3. Thermal Healing Spring P-106 } \mathrm{x}, \mathrm{Dom} \text { Mladost“6 with water temperature of } 40^{\circ} \mathrm{C} \\
\text { 4. Thermal Healing Spring P-161x Varna at "Primorski" swimming pool with water } \\
\text { temperature of } 50^{\circ} \mathrm{C}\end{array}$ & $\begin{array}{l}5-7 \\
5 \pm 1 \\
5-8\end{array}$ \\
\hline 5. Healing spring ,Healing water"6 village of Goren Chiflik & 170-180 \\
\hline
\end{tabular}
is clean.

According to the standard requirements from the examined water samples from the four springs, the water

The presence of coliforms and Escherichia coli is determined by the membrane method, and according to Ginchev’s method. The trial results (Table 3 and Table 4) reveal that thermal healing spring drilling №P-83x Health Resort "Saints Constantine and Helena" with water temperature of $48^{\circ} \mathrm{C}$, thermal healing spring $\mathrm{P}-1 \mathrm{x}$ "Aquarium" with water temperature of $47^{\circ} \mathrm{C}$, thermal healing spring P-106 x "Dom Mladost" with water temperature of $40^{\circ} \mathrm{C}$, thermal healing spring P-161x Varna ate "Primorski" swimming pool, are in compliance with the requirements for presence of coli bacteria. Non-thermal healing spring "Healing water" village of Goren Chiflik does not comply with the requirements for presence of coliform bacteria and enterococci. The given results are also confirmed by the analyses via the membrane method (Table 4). All the remaining indicators are determined by the membrane method.

Table 3. Coli - titre of thermal healing spring waters

\begin{tabular}{|c|c|c|c|c|c|c|c|}
\hline Name of water source & $\begin{array}{c}\text { Coli } \\
- \\
\text { titre }\end{array}$ & $\begin{array}{l}\text { Culture } \\
\text { volumes } \\
50 \mathrm{~cm}^{3}\end{array}$ & $\begin{array}{l}\text { Culture } \\
\text { volumes } \\
10 \mathrm{~cm}^{3}\end{array}$ & $\begin{array}{l}\text { Culture } \\
\text { volumes } \\
10 \mathrm{~cm}^{3}\end{array}$ & $\begin{array}{l}\text { Culture } \\
\text { volumes } \\
10 \mathrm{~cm}^{3}\end{array}$ & $\begin{array}{l}\text { Culture } \\
\text { volumes } \\
10 \mathrm{~cm}^{3}\end{array}$ & $\begin{array}{l}\text { Culture } \\
\text { volumes } \\
10 \mathrm{~cm}^{3}\end{array}$ \\
\hline $\begin{array}{l}\text { 1. Thermal healing spring } \\
\text { Varna } 1 \\
\text { (drilling NoP-83x Health } \\
\text { Resort, Saints Constantine } \\
\text { nd Helena") with water } \\
\text { temperature of } 48^{\circ} \mathrm{C}\end{array}$ & 100 & 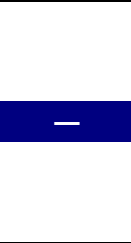 & - & - & - & - & - \\
\hline $\begin{array}{l}\text { 2. Thermal Healing Spring } \\
\text { Varna } 2 \mathrm{P}-1 \mathrm{x} \text { "Aquarium" } \\
\text { with water temperature of } \\
47^{\circ} \mathrm{C}\end{array}$ & 100 & & - & -1 & - & - & - \\
\hline $\begin{array}{l}\text { 3. Thermal healing spring } \\
\text { P-106 } \\
\text { Mladost } \\
\text { temperature of } 40^{\circ} \mathrm{C}\end{array}$ & $\begin{array}{c}> \\
100\end{array}$ & - & - & - & - & - & - \\
\hline $\begin{array}{l}\text { 4. Thermal healing spring } \\
\text { P-161x Varna at at } \\
\text { "Primorski" swimming } \\
\text { pool with } \text { water } \\
\text { temperature of } 50^{\circ} \mathrm{C}\end{array}$ & 100 & - & - & 一 & 一 & 一 & 一 \\
\hline $\begin{array}{l}\text { 5. Non-thermal healing } \\
\text { spring } \\
\text { water }{ }^{66} \text { village of Goreng } \\
\text { Chiflik }\end{array}$ & 70 & $\begin{array}{c}+ \\
\text { Acid }\end{array}$ & $\begin{array}{c}+ \\
\text { Acid }\end{array}$ & $\begin{array}{c}+ \\
\text { Acid and } \\
\text { gas }\end{array}$ & $\begin{array}{l}+ \\
\text { Acid and } \\
\text { gas }\end{array}$ & $\begin{array}{l}+ \\
\text { Acid and } \\
\text { gas }\end{array}$ & $\begin{array}{l}+ \\
\text { Acid and } \\
\text { gas }\end{array}$ \\
\hline
\end{tabular}


Table 4 Microbiological indicators of spring waters in Varna District

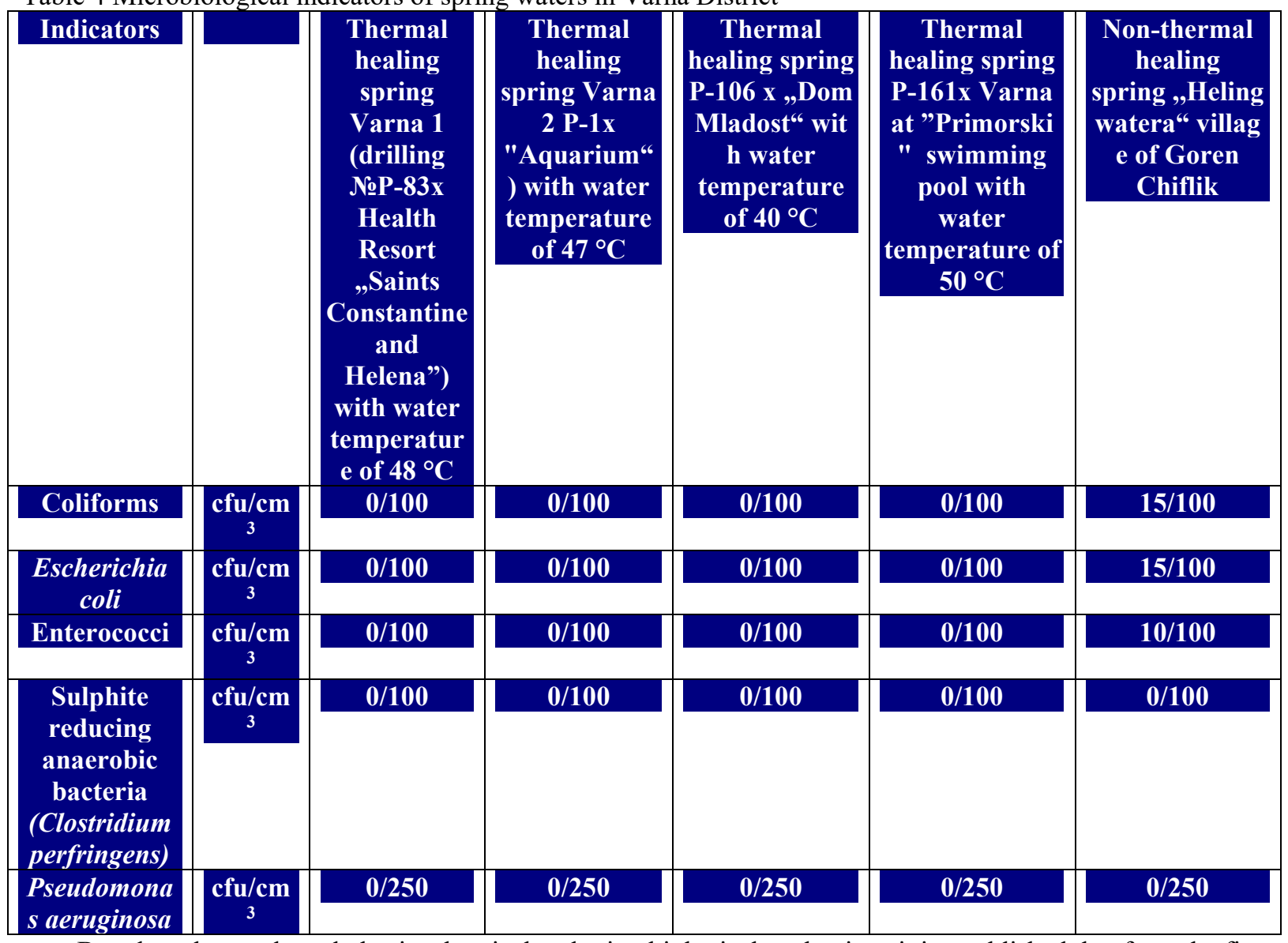

Based on the conducted physicochemical and microbiological evaluations it is established that from the five examined springs at the territory of Varna District only thermal spring water, drilling №P-83xKK "Saints

Constantine and Helena", thermal healing spring water P-1x "Aquarium", thermal healing spring water P106 x "Dom Mladost", thermal healing spring water P-161x Varna at "Primorski" swimming pool correspond to all controlled parameters according to Ordinance № 9 / 2001, Official State Gazette, issue 30, and decree № 178 / 23.07.2004 about the quality of water, intended for drinking purposes, and with regards to microbiological parameters thermal healing water, drilling №P-83xKK "Saints Constantine and Helena", thermal healing spring water P-1x "Aquarium", thermal healing spring water P-106 x "Dom Mladost", thermal healing spring water P$161 \mathrm{x}$ at "Primorski" swimming pool are in compliance with the requirements for drinking water.

"Healing water" village of Goren Chiflik, Varna District does not comply with physicochemical indicators given for nitrates - them being higher than 130 milligrams per litre (Regional Health Inspection (RZI) - Varna), and with regards to microbiological indicators it is not in compliance with the requirements for presence of coliform bacteria and enterococci. According to Ordinance № 9 / 2001, Official State Gazette, issue 30, and decree № 178 / 23.07.2004 about the quality of water, intended for drinking purposes, it is not suitable for drinking.

\section{References}

Belkova, N. L., Tazaki, K., Zakharova, J. R.\&Parfenova, V. V. (2007) Activity of Bacteria in Water of Hot Springs from Southern and Central Kamchatkaya Geothermal provinces, Kamchatka Peninsula, Russia. Microbiol. Research, 162, 99 - 107.

orsheim, K. Y., Bratbak, G. \&Heldal, M. (1990). Enumeration and Biomass Estimation of Planktonic Bacteria and Viruses by Transmission Electron Microscopy, Appl. Environ. Microbiol.. 56, 352 - 356.

BDS 8451 : 1977 - defining of colour according to Rublyovska Scale, determination of smell at $20{ }^{\circ} \mathrm{C}$.

EN ISO 7027 - determination of turbidity.

BDS 3424 : 1981 - determination of $\mathrm{pH}$.

BDS 3413 : 1981 - determination of oxidisability.

BDS 3414 : 1980 - determination of chlorides.

BDS ISO 6058 - determination of calcium, determination of general hardness.

BDS EN 27888 - determination of electrical conductivity. 
BDS $7211: 1982$ - determination of magnesium.

BDS EN ISO 7899 - 2- determination of nitrates.

BDS EN ISO 9308 - 1: 2004 - determination of Escherichia coli and coliform bacteria.

BDS EN 26461 - 2 : 2004 - determination of sulphite reducing anaerobic bacteria (Clostridium perfringens) .

BDS EN ISO 16266 - determination of Pseudomonas aeruginosa.

BDS EN ISO 7899 - 2 - determination of eneterococci.

BDS EN ISO 6222 : 2002 - determination of total number of aerobic and facultative anaerobic bacteria.

Decree № 178 / 23.07.2004 about the quality of water, intended for drinking purposes.

Delley, M., B. Mollet\&H. Hottinger, (1990), DNA Probe for Lactobacillus Delbrueckii, Appl. Environ. Microbiol., 56:1967-1970.

Haglund, A.-L., Tornblom, E., Bostrom, B.\&Travnik, L, (2002) Large Differences in the Fraction of Active Bacteria in Plankton, Sediments, and Biofilm, Microb. Ecol, 43, $232-241$.

Fisher, U. R.\& Velimirov, B., (2000) Comparative Study of the Abundance of Various Bacterial Morphotypes in an Eutrophic Freshwater Environment Determined by ADDC and TEM, J. Microbiol. Methods, 39, 213 224.

Fouke, B. W., Bonheyo, G. T., Sanzenbacher, B.\& Frias-Lopez, J. (2003) Partitioning of Bacterial Communities Between Travertine Depositional Facies at Mommoth Hot Springs, Yellowstone National Park, USA. Can. J. Earth Sci., 40, 1531 - 1548.

Ignatov, I. (2010) Which Water is Optimal for the Origin (Generation) of Life? Euromedica, Hanover, 34-37.

Ignatov I., Mosin O.V. (2013) Possible Processes for Origin of Life and Living Matter with modeling of Physiological Processes of Bacterium Bacillus Subtilis in Heavy Water as Model System, Journal of Natural Sciences Research, 3 (9), 65-76.

Ignatov, I., Mosin, O. V. (2013) Structural Mathematical Models Describing Water Clusters, Journal of Mathematical Theory and Modeling, 3(11), 72-87.

Ignatov, I., Mosin, O.V. (2015) Origin of Life and Living Matter in Hot Mineral Water, Advances in Physics Theories and Applications, 39, 1-22.

Ignatov, I., Mosin, O. V., Velikov, B., Bauer, E. Tyminski, G. (2014) Longevity Factors and Mountain Water as Factor. Research in Mountain and Fields Areas in Bulgaria, Civil and Environmental Research, Vol. 30, No. 4, pp. 51-60.

Ignatov, I. (2018) Research of the Factors of Health and Longevity of for the Population in Bulgaria, Bulgarian Journal of Public Health, 10 (1), 34-50.

Inagaki, F., Takai, K., Hirayama, H., Yamato, Y., Nealson, K. H. \&Horikoshi, K. (2003). Distribution and Phylogenetic Diversity of the Subsurface Microbial Community in a Japanese Epithermal Gold Mine, Extremophiles, 7, $307-317$.

Jeanthon, C. (2000) Molecular Ecology of Hydrothermal Vent Microbial Communities, Antonie van Leeuwenhoek, 77, $117-133$.

Ordinance № 9 / 2001, Official State Gazette, issue 30.

Karner, M.\&Fuhrman, J. A., (1997). Determination of Active Marine Bacterioplankton: a Comparison of Universal 16S rRNA Probes, Autoradiography, and Nucleoid Staining, Appl. Environ. Microbiol, 63, 1208 $-1213$.

Karner, M.\& Fuhrman, J. A. (1997) Determination of Active Marine Bacterioplankton: a Comparison of Universal 16S rRNA Probes, Autoradiography, and Nucleoid Staining, Appl. Environ. Microbiol., 63, 1208 $-1213$.

Kogure, K., Simidu, U., Taga, N., Colwell, R. R., 1987. Correlation of direct viable counts with heterotrophic activity for marine bacteria. Appl. Environ. Microbiol. 53, 2332 - 2337.

Miskin, I., Rhodes, G., Lawlor, K., Saunders, J. R.\& Pickup, R. W.(1998) Bacteria in Post-glacial Freshwater Sediments, Microbiology, 144, 2427 - 2439.

Prieur, D., Erauso, G.\&Jeanthon, C., (1995) Hyperthermophilic Life at Deep-sea Hydrothermal Vents. Planet. Space Sci, 43, $115-122$.

Rodriguez, G. G., Phipps, D., Ishiguro, K.\& Ridgway, H. F. (1992) Use of a Fluorescent Redox Probe for Direct Visualization of Actively Respring Bacteria, Appl. Environ. Microbiol. 58, $1801-1808$.

Schulze-Makuch, D.\& Kennedy, J. F. (2000) Microbiological and Chemical Characterization of Hydrothermal Fluids at Tortugas Mountain Geothermal Area, Southern New Mexico, USA. Hydrogeol. J. 8, 295 - 309.

Takai, K.\&Horikoshi, K. (1999) Molecular Phylogenetic Analysis of Archaeal Intron-containing Genes Coding for rRNA Obtained from a Deep-subsurface Geothermal Water Pool, Appl. Environ. Microbiol.. 65, 5586 5589.

Tumbarski, Y., Valcheva, N., Koleva, I.\& Denkova, Z. (2014)Antimicrobial Activity against Some Saprophytic and Pathogenic Microorganisms of Bacillus species Strains Isolated from Natural Spring Waters in Bulgaria, British Microbiology Research Journal, 4 (12), 1353-1369. 
Valcheva, N. (2014) Microflora of Healing and Spring Waters in Haskovo and Stara Zagora Regions, PhD Dissertation, Faculty of Agriculture, Department „Biochemistry, Microbiology, Physics “, Trakia University, 1-142.

Valcheva, N., Denkova, Z., Nikolova, R., Denkova, R. (2014) Physiological, Biochemical, and MolecularGenetic Characterization of Bacterial Strains Isolated From Spring and Healing Waters in Region of Haskovo, Food, Science, Engineering and technologies 2013, Plovdov, LX, 845-850.

VLM - $\mathrm{NH}_{4}$ - № 1 - determination of ammonium ions.

$\mathrm{VLM}-\mathrm{NO}_{3}$ - № 2 - determination of nitrates.

VLM - $\mathrm{NO}_{2}$ - № 3 - determination of nitrites.

$\mathrm{VLM}-\mathrm{SO}_{4}$ - № 4 - determination of sulphates.

VLM - $\mathrm{PO}_{4}$ - № 5 - determination of phosphates.

VLM - Fe - № 6 - determination of iron.

VLM - Mn - № 7 - determination of manganese.

VLM - F-№ 8 - determination of fluorides.

Ward, D. M., Ferris, M. J., Nold, S. C.\& Bateson, M. M. (1998) A Natural View of Microbial Biodiversity Within Hot Spring Cyanobacterial Mat Communities, Microbiol. Mol. Biol. Rev., 62, 1353 - 1370.

Watson, S. W., Novitsky, T. J., Quinby, H. L., Valois, F. W., 1977. Determination of Bacterial Number and Biomass in the Marine Environment, Appl. Environ. Microbiol, 33, 940 - 946. 